\title{
Mapping of Education Information Networks in Community of Cintaratu Village Pangandaran
}

\author{
Evie Ariadne Shinta Dewi ${ }^{1 *}$, Nindi Aristi ${ }^{2}$, Rachmaniar $^{3}$ \\ ${ }^{1,2,3}$ Faculty of Communication Sciences, Padjadjaran University \\ Hegarmanah, Jatinangor, Sumedang, Jawa Barat, Indonesia \\ Email: evie@unpad.ac.id \\ Email: nindi@unpad.ac.id \\ Email: rachmaniar01@gmail.com
}

\begin{abstract}
This article is based on the results of research which the aim is to find out how is mapping of the education information dissemination network in the community of Cintaratu village, Pangandaran district. The reason for choosing the topic was that Padjadjaran University (Unpad) campus is in the village and it is assumed that the presence of the university in the village could improve the quality of education of its people. To confirm this assumption, it is necessary to map the education sector information network. We use qualitative methods which approach is a descriptive study, the researchers conducted a mapping of educational information dissemination. The main informants of this study are the community and village officials. Data were collected through in-depth interviews, passive participatory observation, and literature studies. The finding of the research are as follows, 1) the initial mapping of educational information dissemination to the community was carried out through direct communication, namely through two major activities - recitation and celebration; 2) recitation and celebration are two activities that are susceptible to physical noise-causing information related to education not conveyed properly to the public. Effective communication does not occur in these two activities.
\end{abstract}

Keywords: network, mapping, dissemination, rural, communities

Paper type: Research paper

*Corresponding author: evie@unpad.ac.id

Submitted: 2020-06-22; Accepted: 2020-10-29; Published: 2020-10-30

Cite this document: Dewi, Evie Ariadne Shinta, Nindi Aristi, \& Rachmaniar (2020). Mapping Of Education Information Networks In Community Of Cintaratu Village Pangandaran West Java. The Journal of Society and Media, 4(2), 279-297. doi: 10.26740/jsm.v4n2.p279-297 


\section{INTRODUCTION}

The problems of poverty, health and education are very complex problems that require joint and coordinated intervention of all parties. Cintaratu is one of the villages in Pangandaran, with this major problem commonly faced by the community, and Indonesian society in general. The community development / empowerment approach has been pursued so far through various sectoral and regional developments. However, because it was carried out with an inaccurate and partial and unsustainable approach, its effectiveness, especially in overcoming social problems, is deemed not optimal (Alfarisyi and Amila 2014; Furchan 2004).

The presence of the Unpad PSDKU Campus in Cintaratu Pangandaran Village is expected to contribute significantly to community development and empowerment. Community service program is one of the three principles of education as an effort to contribute higher education to the Pangandaran community in general and Cintaratu Village in particular (Pancasilawan 2020).

Community empowerment is an economic development concept that summarizes social values. In carrying out community empowerment in an integrated manner, it must be carried out in a cross-sectoral manner and make the community the main actors of development, paying attention to local values, and based on the analysis of the potential existing in the area (Pangandaran 2018; (Qiu, Chen, and Shi 2020)).

In carrying out these community empowerment activities, Unpad's community service programs are cross-sectoral and research-based. This service program is designed in a sustainable manner, so that in 2020 community service is designed on research-based mapping of regional potential, which will be used as a basis for carrying out community service (Ananda 2016; Fitriyadi 2013).

Pangandaran Regency, located in the South of West Java Province, is known for its extraordinary natural tourism potential. As a new district that was established independently since 2012, the Regency Government prioritizes tourism management in all aspects, which is also supported by the Provincial Government of West Java and the Central Government (Bakti 2020).

The tourism sector is perceived as the right solution to quickly change the economic situation of Pangandaran Regency people. It is indicated by the budget portion allocated for the Tourism and Culture Office in 2019, which was Rp. 
37,319,349,000 - for structuring the west coast and east coast of Pangandaran following Global Sustainable standards Tourism Council (GSTC) (Ningsih 2018).

The changes in the economic situation are indeed fundamental and essential for the local government and especially the community, without having to ignore other substantial things that need attention from the Pangandaran Regency Government, such as the education sector. It is in line with the reality of the Education Index issued by Human Development Reports in 2017, Indonesia ranked seventh among ASEAN countries. It shows that Indonesia's human resources competitiveness is still low compared to Singapore, Malaysia, etc.

\section{Figure 1}

\section{Education Index 2017 Quoted}

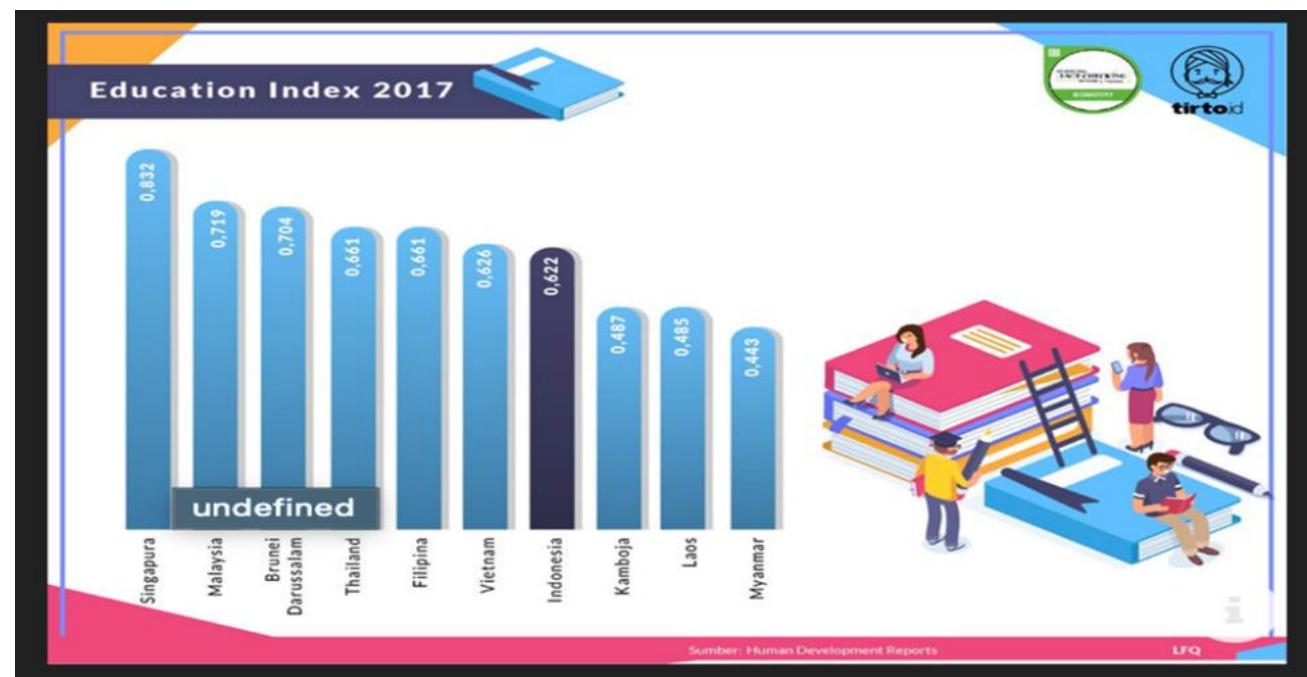

Source : www.tirto.id

Pangandaran is one of the districts in West Java, which is famous for its natural tourism potential. This Regency has existed since 2012, where the Regency Government prioritizes various aspects related to tourism with the support of the Provincial Government of West Java.

The effort is conducted since the tourism sector is considered to be a problem solver to change the economic life of Pangandaran Regency people, besides the education sector.

Several educational programs of the Ministry of Education in 2019 have been widely echoed to the public through mass media, including the Smart 
Indonesia Program, School Operational Assistance (BOS), construction/rehabilitation of educational facilities, and Bidik Misi scholarships (Setiaman 2013; Li et al. 2020).

The mission of each educational assistance program is to build Indonesian human resources, starting from school-age children so that they can get primary education up to higher education. However, it cannot be denied that there are still several problems from the side of government policy to the technical distribution of aid-to-aid recipients (Warsono 2017).

In 2019, data from the Education, Youth and Sports Office (Disdikpora) of Pangandaran Regency shows that the total of Rp. 26,000,000,000 was budgeted from the Special Allocation Fund (DAK) with details of Rp. 7,089,000,000, for junior high schools and Rp. 19,360,000,000, - for elementary schools. The fund was used to repair 178 school buildings, including classrooms rehabilitation, teacher's room, and toilet facilities (harapanrakyat.com). Nevertheless, there are still concerns that the education budget is not channeled to programs that the community needs and it is not on target.

Figure 2

Infographic of the Education Budget Misuse

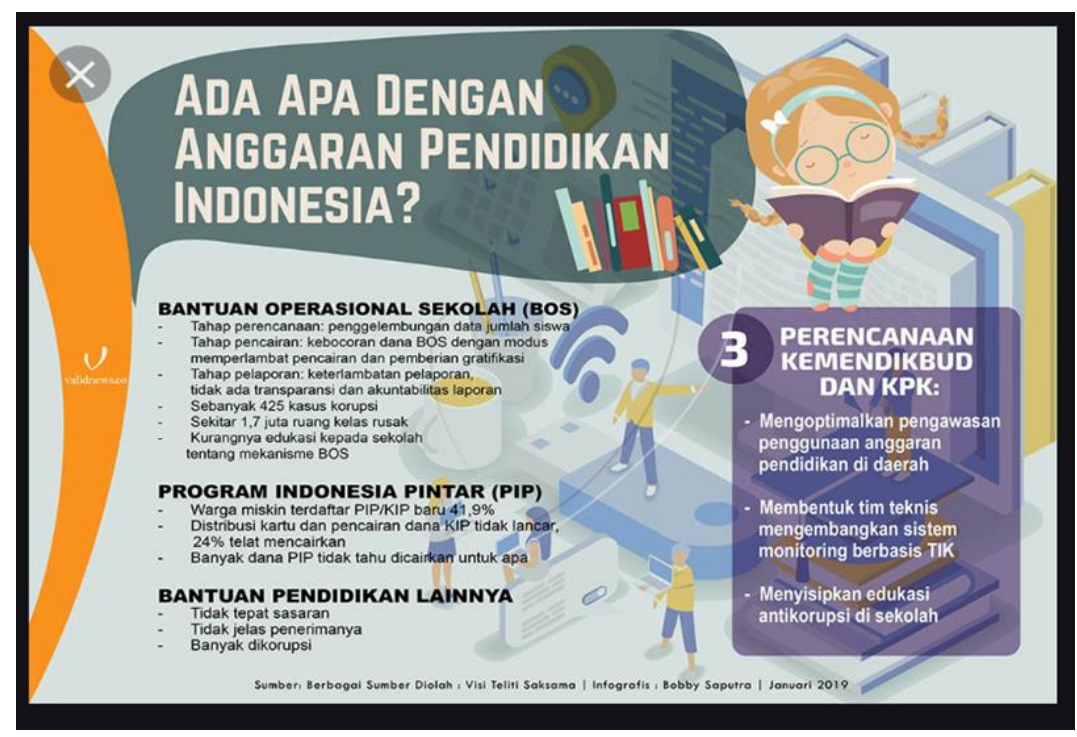

This situation is indeed quite reasonable, considering that the Education, Youth, and Sports Office in Pangandaran Regency should be able to play a role as a liaison provider of educational information for the entire community of 
Pangandaran Regency, in fact, their presence is not yet optimal. It can be seen from the management and availability of public information on page http://web.pangandarankab.go.id/public/skpd/disdikpora/.

When researchers tried to enter the topic of public information on the website, apparently, no information appeared, as seen from the figure bellow.

Figure 3

\section{Lack of Education Information Displayed on The Official Page of} The Education

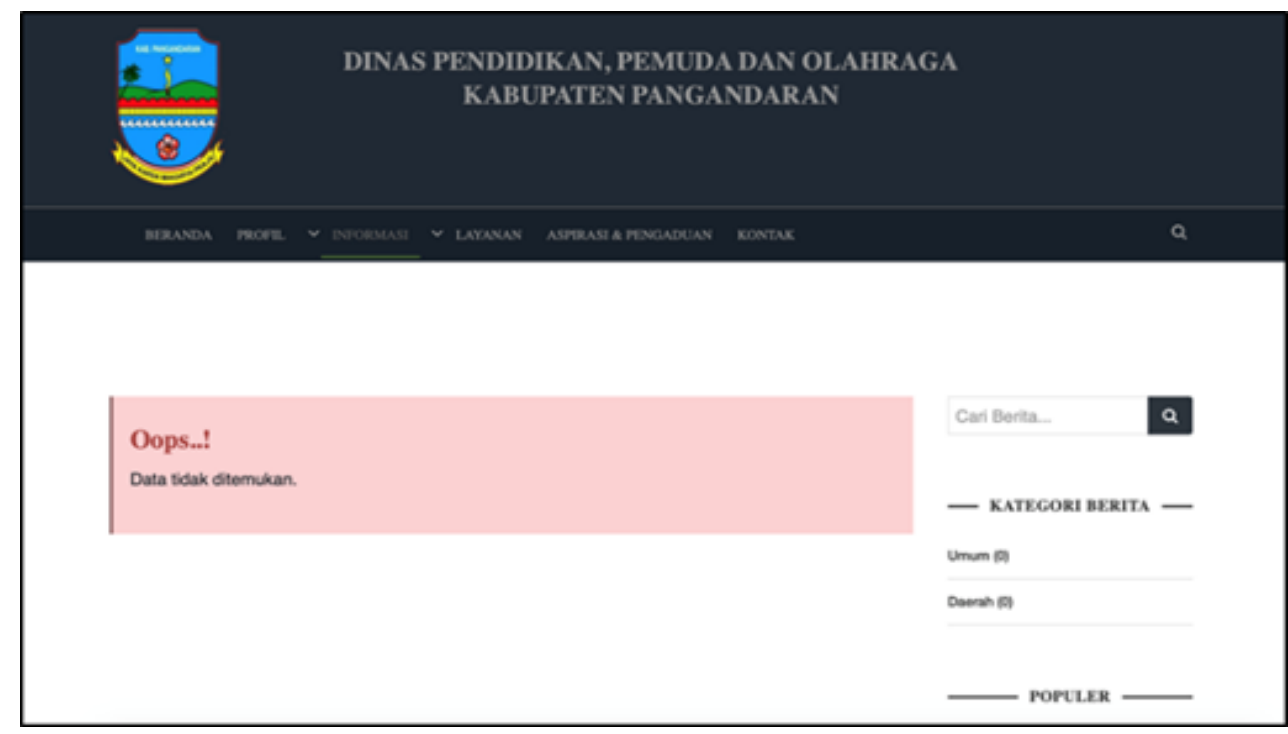

Source : Youth and Sports Office in Pangandaran Regency (2019)

For this, it is known that there is still a lack of public information related to education for the people of Pangandaran Regency.

Seeing the phenomenon that occurs on the official page of the Education, Youth and Sports Office in Pangandaran, It is interesting to see the Mapping of Early Dissemination of Educational Information in the Community of Cintaratu Village, Pangandaran Regency.

In the context of education, Cintaratu Village is unique. It deserves special attention, considering that starting in 2019, the Study Program Outside the Main Campus (PSDKU), University of Padajadjaran (Unpad), which has been operated in Pangandaran Regency since 2016, has built its campus in this village. 
The presence of five Study Programs Outside the Main Campus of Unpad, namely Business Administration, Communication Studies, Animal Husbandry, Fisheries and Marine Science, and Nursing, is believed to be able to bring access to quality higher education services while at the same time it is able to develop regional potentials that have an impact on increasing the welfare of the Pangandaran community, including of course Cintaratu village community.

A small village on the mountain, which was initially quiet seems to have begun to have a new socio-cultural order, with the presence of the campus, the village community slowly began to squirm dynamically. Students, parents, lecturers, and education staff begin to come to this 1,029-hectare village to carry out various academic activities, not just lectures but also research and community service. The social linkage between the migrant groups and the residents of origin is expected to increase the appreciation of the life of the Cintaratu villagers, especially since Unpad is an educational institution, so it should be able to transform the village community through structuring the education sector.

Cintaratu Village is a village in Parigi District with an area of 1,029 hectares and is located $29 \mathrm{kms}$ from Pangandaran beach. The existence of this village can be said quite far from the center of public activities.

The education index and the people's purchasing ability contribute significantly to the achievement of the Human Development Index (HDI) of Cintaratu Village, Parigi District, and Pangandaran Regency each year. Furthermore, this contribution can be felt significantly.

\section{Tabel 1}

Human Development Index of Cintaratu Village, Pangandaran Regen

\begin{tabular}{|c|c|c|c|c|}
\hline \multirow[t]{2}{*}{ NO } & \multirow[t]{2}{*}{ URAIAN } & \multicolumn{3}{|c|}{ TAHUN } \\
\hline & & 2015 & 2016 & 2017 \\
\hline 1 & Indeks Pendidikan & 85,71 & 86,91 & 87,69 \\
\hline 2 & Indeks Kesehatan & 62,07 & 63,16 & 64,34 \\
\hline 3 & Indeks Daya beli & 73,75 & 74,93 & 75,66 \\
\hline$*$ & $\begin{array}{l}\text { Target IPM Kecamatan } \\
\text { Parigi }\end{array}$ & 72,38 & 75,70 & 77,70 \\
\hline$*$ & $\begin{array}{l}\text { Target IPM Kabupaten } \\
\text { Pangandaran }\end{array}$ & 73,38 & 73,00 & 75,89 \\
\hline & REALISASI IPM & 73,84 & 74,84 & 75,89 \\
\hline
\end{tabular}


Responding to the index, certainly, the people of Cintaratu Village have hopes for the openness and clarity of the dissemination of educational information, especially for children who are at school age.

In terms of the existing background of work, the majority of Cintaratu Village people work as farmers and laborers. This condition certainly happens because of the limited education they have. They also hope that the education that will be received by the next generations can bring significant changes to the welfare of the family.

Then for the use of mobile phones, it is known that as many as 3,227 people of Cintaratu Village use it in the context of searching for information and communication media.

For this reason, the existence of public information related to education should be conveyed quickly, easily, and without other demographic constraints. Nevertheless, the facts show that education-related information is still difficult for the people of Cintaratu to access, causing the community not to understand the information even they do not receive any educational information (Mutiah 2017).

Educational programs such as the Smart Indonesia Card, School Operational Assistance, and scholarships allocated to the poor people are not optimally absorbed. Seeing this, surely, it is necessary to do an Initial Mapping of Information Dissemination of Education in the Cintaratu Community to obtain valid, reliable and empathic educational data. To answer this, the authors use the concept of direct communication, effective communication, noise, and make a qualitative approach, with a descriptive research tradition (Heriyanto 2019; (Winters, Karim, and Martawardaya 2014)).

The novelty of this research is that even though the Cintaratu Village Community is accustomed to using cellphones, these devices are not used to increase information retrieval about government programs in education. Communication and educational information are delivered by officials to communities prefer use face-to-face meetings than through digital communication media such as cellphones. 


\section{METHOD}

According to Mc Leod (2004) in Sutopo (2012) information is useful data that is processed so that it can be used as a basis for making correct decisions. Information is a very important commodity, because the information will help in day-to-day operations and decision making (Johnson and Christensen 2012; Kountur 2003).

Information is no longer considered something that only functions as information that can be used as a tool to fulfill knowledge, but more than that information has an important role in human life today. Information becomes a necessity for humans, even with information humans can think to make decisions related to life (Babbie 1989).

Data collection techniques have a very decisive role for researchers to obtain valid data, in the sense of describing what is true and reliable and objective (De Vaus 2014; Denzin and Lincoln 1994).

In carrying out this community service, so that the data obtained is valid, reliable and objective, also accurate and relevant and in accordance with the needs of the activity and data analysis can be carried out properly, it must be determined the type of method to be used in the data collection technique (Gast 2010).

The method used in the implementation of this activity is to use a survey method through a simple questionnaire. The data used in this research is primary data, which is directly obtained from the source. The method to be used in data collection efforts related to this research is the distribution of questionnaires. The distribution of questionnaires is a data collection technique by distributing questions to many respondents and must be answered by a specified number of respondents (Berg and Howard 2012).

Collecting data using a questionnaire is the primary data source for writing. The questions used in the questionnaire in this study are closed questions. Closed questions were chosen because it makes it easier for the author to process and analyze data, and also makes it easier for respondents to answer questions where all the questions already have alternative answers. This questionnaire will be distributed to the community of Cintaratu Village (Sudjana dan Ibrahim 1989; Leedy and Ormrod 2014).

In addition to questionnaires, interviews and observations were also carried out to collect complete and detailed data in order to find out the real 
problems faced by the Cintaratu Village community and then to help the team develop appropriate and targeted communication and information strategies.

\section{RESULTS AND DISCUSSION}

Community development activities are activities that aim to develop a particular group in an area. This community development is commonly known as community empowerment. There are several definitions regarding the concept of empowerment. According to Ife (in Martono, 2011) defines the concept of community empowerment as a process of preparing people with various resources, opportunities, knowledge, and expertise to increase the capacity of the community in determining their future, as well as participating and influencing life in the community itself. Meanwhile, Kartasasmita (1995) argues that community empowerment is an effort to increase the dignity and dignity of the community to escape the traps of poverty and underdevelopment. The point is that community empowerment aims to give birth to an independent society by creating conditions that allow the potential of the community to develop. Each region has potential which, if utilized properly, will help improve their quality of life and escape backwardness and dependence. The community has an important role in the community empowerment effort, because the community is the subject of empowerment. So community empowerment is not fully the responsibility of the government (Gumilar 2014).

Empowerment is a process of developing, independent, self-empowering, and strengthening the bargaining position of the lower classes of society against the pressing forces in all fields and sectors of life (Sutoro, 2002). The concept of empowerment (village community) can also be understood from two perspectives. First, empowerment is interpreted in the context of placing the community's standing position. The position of the community is not only the object of beneficiaries who depend on gifts from outside parties such as the government, but in the position of the subject (agent or acting participant) who acts independently. Doing independently does not mean being separated from the responsibility of the state. Providing public services (health, education, housing, transportation and so on) to the community is certainly obligatory. An independent society as a participant means opening up space and capacity to 
develop creative potential, controlling the environment and its own resources, solving problems independently, and determining the political process in the realm of the state. The community participates in the development and governance process (Sutoro 2002; Karsidi 2017).

Based on the concept about empowerment above, we found some results of research, ie: the people of Cintaratu Village expect openness and clarity in the dissemination of information on special education for school-aged children. Since most of the people have the employment background mostly as farmers and laborers, education determines how to change their lives. By obtaining specific titles, it is hoped that village life will change in a better direction.

The use of mobile phones as communication media and the needs of information seeking reaches 3,157 users from Cintaratu Village. Through real media, public information related to education can be disseminated quickly, easily, and without other demographic challenges. Information about education is still difficult to obtain for the people of Cintaratu Village, so it has made people stay away and not receive educational information such as the Smart Indonesia Card, School Operational Assistance, and scholarships offered specifically for the poor.

There is a need to map the information and communication networks related to education oriented to the situation, circumstances, and expectations of the people of Cintaratu Village, so that in the future, a valid, reliable, and empathic education data can be obtained (Ginanjar, Bambang and Tri 2012).

Initial mapping is an effort made to see how the initial determination of programs and priorities for a matter can be applied to a location through government efforts, private sector, or organizations related to these programs and priorities. While dissemination is an activity of spreading information intended for groups, targets, or individuals to get them all to get information so that they all have awareness, receive, change the target's behavior, and in the end, they all can use the available information.

Following is the data obtained from the questionnaire, as shown in Figure $6,37 \%$ of respondents representing Cintaratu villagers are aware of educational assistance in the form of the Smart Indonesia Program and 15\% of them are aware of School Operational Assistance while $37 \%$ of them say that they know about the two programs, and only $11 \%$ say that they have no idea. 
The primary sources of information about education assistance from the government are mostly obtained from television (24\%), family (19\%), village officials $(12 \%)$, neighbors $(10 \%)$, school teachers $(8 \%)$, newspapers $(5 \%)$, radio (4\%), announcement board (2\%) and absolutely none $(0 \%)$ that makes mobile phone as a medium for obtaining information on scholarships.

\section{Figure 4}

\section{Knowledge of Education Assistance Information \& Information Sources}
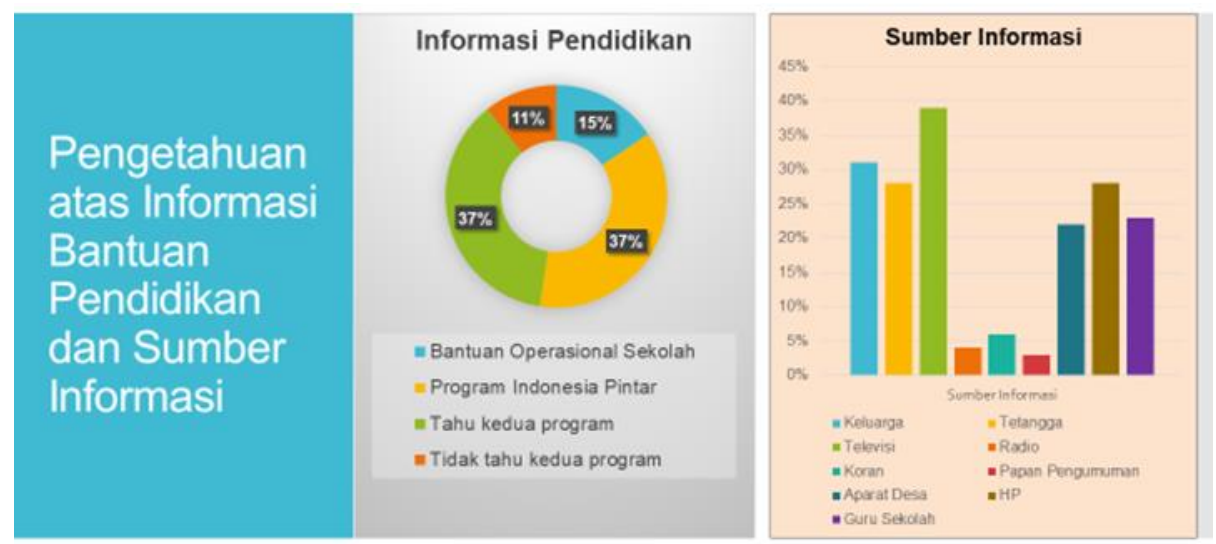

Respondents' knowledge about the two Scholarship Programs, namely the 3T Featured Scholarship program and the Community Achievement Scholarship program, are not owned by almost half $(46 \%)$ of respondents. At the same time, the rest stated that they knew there were a Community Achievement Scholarship program (37\%) and the 3T Featured Scholarship program (7\%) and $12 \%$ of the respondents stated they did not know any of them. The source of information is almost the same as the information on education assistance, mostly obtained through television, families, village officials, neighbors, and school teachers. While newspapers, radio, and bulletin boards are used very little as sources of information, particularly mobile phones, they are hardly used to find scholarly information.

\section{Figure 5}

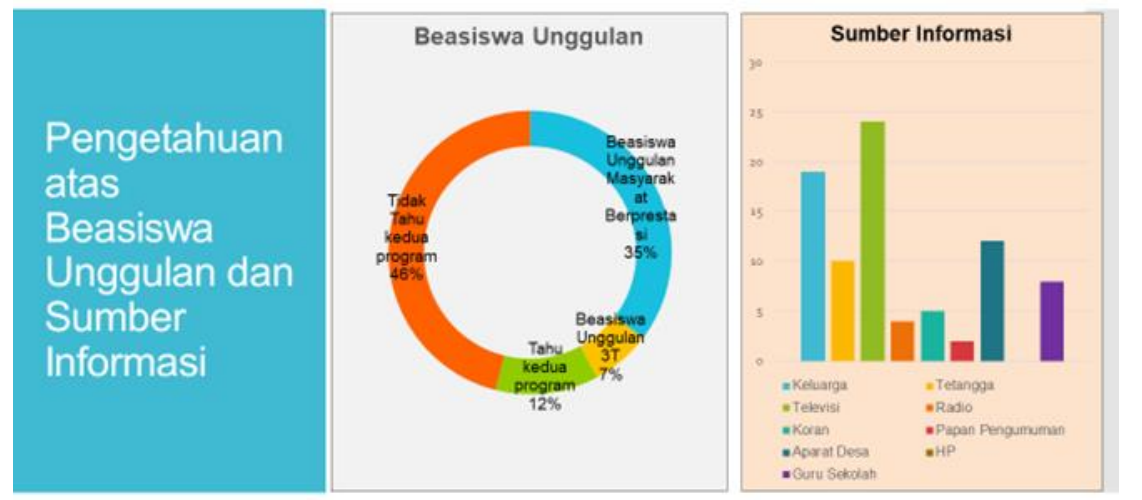




\section{Knowledge of Scholarships and Sources of Information}

Nevertheless, strangely, Figure 5 shows that the respondents' preference in finding educational information; the highest is mobile phones $(55 \%)$. The second source is family (35\%), television (32\%), neighbors (22\%), and surrounding village apparatuses $10 \%$, while notice boards, newspapers, and radios are not used as a preference in seeking educational information.

\section{Figure 6}

\section{Preferences of Educational Information Sources}
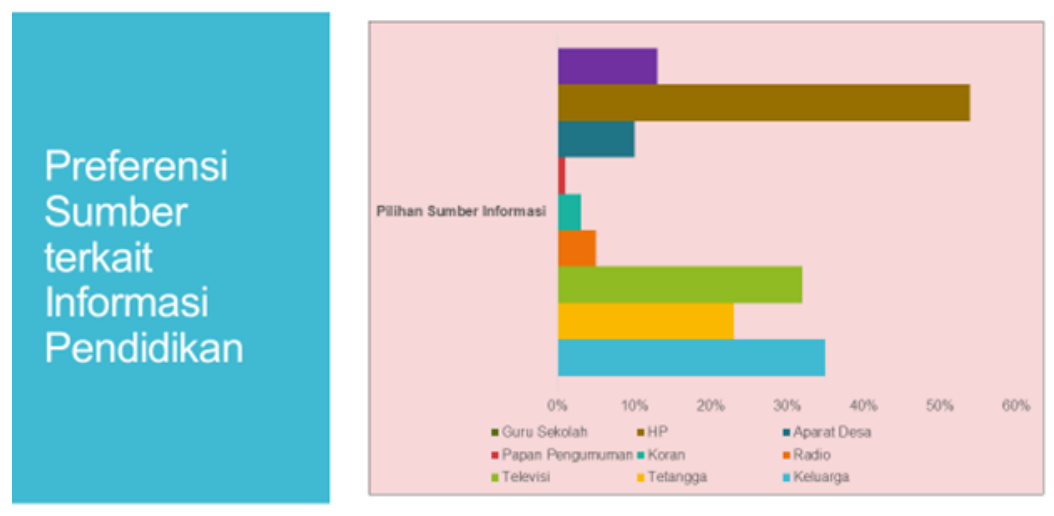

From the result of this research, there are exciting things to be observed and carried out in a more in-depth study, namely the fact that the Cintaratu villagers are well-informed with educational assistance programs such as BOS and the Smart Indonesia Card (KIP). Even in the FGD, it was revealed that the KIP program was considered right on target; it only needed improvement in terms of the database. This is essential because KIP is a central program, so that village officials feel that they are not involved in the data collection process of who is entitled to receive KIP. So that in the field, there was a bit of a riot because the inaccurate data caused many residents. The ones who should have met the criteria, in fact, they were not included in the list of recipients. According to a village official in the FGD, the data used for KIP assistance was 1991 data (Bahar 2017).

The solution for this seems to have good coordination between the central and regional governments, especially the village government, in collecting data on the sparse population. Besides that, the village government should update the data independently, so that the population data in the village is always up to date when it is needed by the central government. 
On the other hand, there are citizens who, in some cases, realistically should include poor people who are entitled to KIP, but in the practice, they do not want to accept the label of the poor, so they refuse to accept the assistance.

Meanwhile, for the School Operational Assistance (BOS) fund, the village apparatuses and the community are not directly involved. The funds go to schools and are managed by the school together with the School Committee and supervised by the Education Office. The community is never involved in the process of determining the program and allocation of these funds. In this case, in the future, the village government should be involved with at least the ex-officio head of education in the School Committee.

In the FGD, it was also revealed that the media, which was considered the most effective way to convey information about the education program, was faceto-face communication. Counseling and formal meetings, such as parents' meetings at school, become the primary information media. Besides, informal information delivery is also considered quite practical, for example, information delivered by the speech given by the village officials at the events organized by the residents such as a wedding celebration, circumcision, social gathering, ngayun and other events.

Concerning scholarship information, Cintaratu villagers only knew this information through schools; there had never been a village apparatus who provided information about the existence of a scholarship program from the government. Almost all respondents stated that they had not received any information about scholarships to continue their education to higher education, except for one respondent who happened to be a teacher, so that he had sufficient access to obtain information on scholarships.

In addition to the above findings, in the initial mapping of education information dissemination to the people of Cintaratu, Pangandaran Regency, the initial mapping process related to education information, it was found that the community received educational information through direct communication between village officials and the community. Theoretically, direct communication is a communication process that is carried out directly or face to face. It is like when someone is talking to other people where intermediaries or communication media as a conduit of messages or information are not in the communication 
process. This direct communication generally occurs in activities attended by the community and village officials, such Recitation and Celebration activities, which we described bellow.

Recitation is a word that has been very popular for the people of Indonesia, as well as in the people of Cintaratu, Pangandaran Regency. The word "recitation" actually comes from the word aji, which has a good understanding, and when the prefix pe and suffix are added, the word has the meaning of making aji or making good.

For that reason, recitation is an activity that aims to make someone who participates in the event expected to be a good person. In the language of religion, the word aji or good is interpreted as a pious person or sholihah.

Furthermore, it must be admitted, and until now, the recitation activity is one culture that is still well embedded in the people of Indonesia, as well as the people of Cintaratu, Pangandaran Regency.

In the recitation held in the Cintaratu community, of course, there is a social interaction that occurs between the members of the recitation whom are the community and village officials. Moreover, just as the study is conducted in several places, the speech given by the village officials often becomes part of the recitation program. At that time, in this case, the village head or village secretary, or other apparatus assigned to attend the study, also included valuable information related to education. Furthermore, from the community, Cintaratu is expected to find out information related to education.

A celebration is a party, commemoration, or thanksgiving for something, such as marriage and circumcision. A celebration is a tradition of Indonesia, including Cintaratu people who still hold this tradition.

Just like recitation, in celebration, parties who are celebrating a party or thanksgiving often invite the surrounding community and also village officials. Then, to respect the village officials who have attended the celebration, those who are celebrating a party or thanksgiving usually ask the village officials - the Village Head or the Village Secretary, or the village officials who represent him to give a speech in front of the surrounding community.

When giving these remarks, village officials may provide information related to education, so as to expect that the villagers would be well-informed. 
If it is examined in terms of two activities - recitation and celebration, using the perspective of communication effectiveness, these activities certainly cannot be considered as a form of effective communication.

Effective communication is communication that occurs when the message is delivered can be received well and not misinterpreted; communication processes that can cause effects in accordance with the expectations of the participants (communicators and communicants), where the communication effects include cognitive aspects (changes in knowledge), affective effects (changes in attitude), and psychomotor effects (changes in ability/skills).

Effective communication is communication that causes changes in the target audience from the condition of "not knowing" into "knowing", from the condition of "not wanting" into "to be willing", and "not being able" into "be able"; communication that must be able to turn people who are not willing into fond willingly, and it certainly goes through a particular communication model.

Based on these two meanings, it is known that the message delivered at the time of the study and celebration may not be listened to correctly and understood well. When attending the recitations or celebrations, the focus of the community is to listen to lectures or to see and enjoy the celebrations and parties while things outside of it all, certainly do not become their focus. In communication, this kind of thing is commonly referred to as noise - physical noise, which is the environmental noise is a disturbance that is around the communicator and the communicant where physically it can be heard, seen, or felt that could interfere with the communicator and communicant in terms of delivering messages.

If at the time of providing educational information, the public listens well, and no noise occurs, of course, the information can be absorbed as expected. However, if the information contains quite a lot of data, and when there is noise, of course, the public will have difficulty in knowing the details of the information. Furthermore, hence the provision of information related to education is ineffective. 


\section{CONCLUSION}

From the results of data analysis, it can be concluded that the majority of the people of Cintaratu Village are aware of the existence of educational assistance programs from the government in the form of School Operational Assistance (BOS) \& Smart Indonesia. Card (KIP). However, most people do not know about the Scholarship Program. In addition, the community was not involved in the implementation of education development in schools, especially in the formulation of programs with the allocation of BOS funds, except for residents who were active in the School Committee. The people of Cinta Ratu Village also feel the need for an educational assistance program, but there needs to be a better population data improvement so that assistance is received on target. Regarding the media most widely used by the Cintaratu villagers to seek information about education, television is the main media besides family, village officials, neighbors, and teachers. While newspapers, radio and bulletin boards are used very little as access to educational information. On the other hand, so far the people of Cintaratu Village have almost no knowledge that cellphones as a communication medium owned by most of the community can be used as a medium to find educational information. The media that is considered the most effective for conveying educational information in Cintaratu village is face-to-face meetings, both formal such as counseling and school meetings, and informal such as remarks delivered by village officials during community celebrations, or events such as arisan, ngayun, etc. The village government is not the main source of educational information, but schools (through parent-student meetings and information from teachers to students) are the main source of educational information. Cellular is the most preferred source of educational information apart from family, television, and neighbors.

\section{Recommendation}

1. Considering mobile phones, family, television, and neighbors are the main preferences in seeking educational information, and the researchers recommend that local governments and village governments can educate citizens to be more intelligent in optimizing cell phones' use as access to obtain educational information.

2. It is recommended that the village government, in collaboration with Unpad, have a website that provides information about education and other 
information so that the Cintaratu village community is more open in their insights about government education assistance programs the scholarship program.

3. It is recommended that the Cintaratu village government collaborate with Unpad students to update population data and serve the central government's needs when it reduces educational assistance.

Acknowledgment

This article is the result of research funded by Padjadjaran University, for that we would like to thank Unpad especially PSDKU Pangandaran for allocating research grants and community service. In addition, we also thank the Cintaratu Village government specifically and the Pangandaran district government who have helped us to provide various facilities available at the study site. Our gratitude also goes to the community who are enthusiastic about being an informant and giving honest answers to our interviews. Finally, we also invite students of PKM PSDKU Pangandaran who have high dedication to help collect data in the field. Hopefully all this effort can help contribute to the development of science and also to the people of Cintaratu Village and the general community of Pangandaran district.

\section{REFERENCES}

Alfarisyi M.I., Rispianda, Amila K. 2014. Rancangan Sistem Informasi Layanan Alumni ITENAS Berbasis Web, Jurnal Reka Integra, 2:1,132-143.

Ananda D., 2016. Pemodelan Sistem Informasi Layanan Karir dan Alumni Politeknik, Prosiding pada Seminar Nasional Teknologi Informasi dan Multimedia, STMIK Amikom, Yogyakarta, 43-48.

Babbie, E. 1989. The Practice of Social Research, 5th edition. Belmont CA: Wadsworth.

Bakti, Iriana.2020. Komunikasi Internal Dalam Membangun Kohesivitas Kelompok Pegiat Wisata Di Kabupaten Pangandaran, Jurnal of Social Sciences and Humanities Sosiohumaniora, DOI https://doi.org/10.24198/sosiohumaniora.v22i2.25774

Berg, B. L. and Howard, L. 2012. Qualitative Research Methods for the Social Sciences. (8th ed). USA: Pearson Educational Inc. 
De Vaus, D. A. 2014. Surveys in Social Research. (6th ed). Australia: UCL Press

Denzin, N.K. and Lincoln, Y.S. 1994. Handbook of Qualitative Research. Thousand Oaks: Sage.

Fitriyadi, Herry. 2013. Integrasi Teknologi Informasi Komunikasi dalam Pendidikan: Potensi Manfaat, Masyarakat Berbasis Pengetahuan, Pendidikan Nilai, Strategi Implementasi Dan Pengembangan Profesional, Jurnal Pendidikan Teknologi dan Kejuruan, Volume 21, Nomor 3, Mei 2013

Furchan, A. 2004. Pengantar Penelitian dalam Pendidikan. Yogyakarta: Pustaka Pelajar Offset

Gast, D. L. 2010. Single Subject Research Methodology in Behavioral Sciences. New York: Routledge.

Ginanjar A., Bambang E.P., and Tri I. 2012. Pembuatan Website Profil Sekolah Sebagai Media Informasi Dan Promosi, Jurnal Teknik Informatika, 9:2.

Gumilar, Gumgum. 2014. Penggunaan Media Massa dan Internet sebagai Sarana Penyampaian Informasi dan Promosi oleh Pengelola Industri Kecil dan Menengah di Bandung Jurnal Kajian Komunikasi, Jurnal Kajian Komunikasi (JKK) Vol.2, No.1, Juni 2014

Heriyanto, R.W. 2019. Mapping Management of Geographic Information Systems Distribution of Post-Earthquake Disaster Areas in Padang Pariaman Regency. Proceeding of the National Seminar on Information Technology, Communication and Industry (SNTIKI) II.ISSN (Online): 2579-5406. Pekanbaru: Faculty of Science and Technology, UIN Sultan Syarif Kasim Riau.

Johnson, B. and Christensen, L. 2012. Educational Research, Qualitative, Quantitative and Mixed Approach. (4th ed). California: SAGE Publication.

Kountur, Ronny. 2003. Metode Penelitian Untuk Penulisan Skripsi dan Tesis. Jakarta: PPM

Karsidi, R. 2017. Budaya Lokal Dalam Liberalisasi Pendidikan. The Journal of $\begin{array}{llll}\text { Society } \quad \text { and } & \text { Media, } & \text { 1(2), }\end{array}$ doi:http://dx.doi.org/10.26740/jsm.v1n2.p19-34

Leedy, P. and Ormrod, J. E. 2014. Practical Research Planning and Design. (10th ed). Edinburgh: Pearson Educational Inc.

Lincoln, Y. S. \& Guba, E. G. 1985. Naturalistic Iinquiry. Beverly Hills, CA: Sage 
Mutiah. 2017. Membangun Sistem Komunikasi Indonesia Yang Kolektif Lewat Media Tradisional. The Journal of Society and Media, 1(2), 75-85. doi:http://dx.doi.org/10.26740/jsm.v1n2.p75-85

Li, J. B., A. Yang, K. Dou, L. X. Wang, M. C. Zhang, and X. Lin. 2020. ... Severity, and Perceived Controllability of the COVID-19 and Their Associations with Emotional and Behavioural Reactions, Social Participation, and Precautionary .... psyarxiv.com.

Ningsih, S. T., UJSJ Sucipta, and ... 2018. "IMAJINASI DESA IMPIAN: Konstruksi Media Dalam Pengembangan Desa Wisata Di Desa Ranuklindungan Kabupaten Pasuruan.” The Journal of Society and ....

Qiu, Y., X. Chen, and W. Shi. 2020. "Impacts of Social and Economic Factors on the Transmission of Coronavirus Disease 2019 (COVID-19) in China." Journal of Population Economics.

Winters, Matthew S., Abdul Gaffar Karim, and Berly Martawardaya. 2014. "Public Service Provision under Conditions of Insufficient Citizen Demand: Insights from the Urban Sanitation Sector in Indonesia." World Development 60:31-42.

Pancasilawan, Ramadhan. 2020. Mitigation Of Disaster Risk Reduction In Pangandaran Regency, Jurnal of Social Sciences \& Humanities Sosiohumaniora, DOI https://doi.org/10.24198/sosiohumaniora.v22i2.25774

Pangandaran, G.O. 2018. LKIP Pangandaran Regency Government in 2018.

Setiaman, Agus. 2013. Implementasi Kebijakan Keterbukaan Informasi Publik, Jurnal Kajian Komunikasi (JKK) Vol.1, No.2, Desember 2013

Bahar, Soegiarto. 2017. Model Pemetaan Kompetensi Pada Area TIK Menggunakan Sistem Informasi Berbasis Web, IJNS - Indonesian Journal on Networking and Security, Vol 6, No 4 (2017)D, OI: http://dx.doi.org/10.1123/ijns.v4i3.278

Sudjana, Nana dan Ibrahim. 1989. Penelitian dan Penilaian Pendidikan. Bandung: Sinar Baru

Warsono. 2017. Guru: Antara Pendidik, Profesi, Dan Aktor Sosial. The Journal of Society and Media, 1(1), 1-10. doi:http://dx.doi.org/10.26740/jsm.v1n1.p110 